\title{
Marta Cobel-Tokarska, Marcin Dębicki, Słowo i terytorium. Eseje o Europie Środ- kowej. Warszawa: Wydawnictwo Akademii Pedagogiki Specjalnej, 2017, 269 s.
}

$\mathrm{K}$ siążka stanowi poetycki kolaż na temat Europy Środkowej (czy też Środkowo-Wschodniej). Jest dziełem na temat mieszkańców tej części naszego kontynentu, literatury krajów do niej należących i o niej piszących, literatów, książek, wydawnictw, gór (Karpaty), grup etnicznych i narodów. Jest pisana językiem lekkim, niekiedy wyszukanym. To zbiór kilku esejów na tematy związane z Europą Środka.

Pracę utrzymano w stylu poetyckim a nie ciężkim, scjentystycznym - nieco postnowoczesnym w podejmowaniu różnych tematów. W szkicach widać zainteresowania naukowe, turystyczne, kulturowe, literackie i w znacznym stopniu etnograficzne autorów. Książkę czyta się łatwo - wciągają zwłaszcza niektóre eseje - jest inteligentna, błyskotliwa i w wielu miejscach erudycyjna. Można ją nazwać mozaiką, a nie regularnym, ustrukturowanym, akademickim, ciężkim w percepcji wykładem.

Prezentowany tom nie stanowi przypadkowego zestawienia, jakby się na pierwszy rzut oka mogło wydawać - składa się bowiem z części podejmujących wspólną kwestię, jaką jest Europa Środka. Całość wyłania się stopniowo, kolejne eseje łączą się dzięki podejmowanym w nich problemom. Książka zawiera wiele z osobistego spojrzenia na Europę Środkową, stanowi uwarunkowany doświadczeniami autorów subiektywny ogląd naszej części kontynentu.

Nim przejdę do omówienia tekstu poświęconego Białorusi - co jest zrozumiałe, jeśli uwzględnimy fakt, że „Studia Białorutenistyczne” skupiają się głównie na naszym wschodnim sąsiedzie - krótko przedstawię zagadnienia zawarte w pozostałych rozprawach. W pierwszej z nich odniesiono się do dyskusji toczonych wokół pojęcia Europa Środkowa, w następnym porównano dwa środkowoeuropejskie etnosy - Żydów i Cyganów - w ich różnych historyczno-kulturowych znaczeniach, co okazało się pouczające i wywołuje różne, także socjologiczne, refleksje. Sporo uwagi poświęcono Karpatom (w tym Bieszczadom i Beskidowi Niskiemu), piszącym o nich Andrzejowi Stasiukowi i Słowakowi Marošowi Krajňakowi oraz - oddzielnie - Krzysztofowi Vardze. Sądzę, że warto przytoczyć cytat oddający realia wschodniej Słowacji, ponieważ przypomina on realia białoruskie. „Są wsie, gdzie w ankietach 100 procent mieszkańców deklaruje, że są Słowakami. A w rzeczywistości wszyscy rozmawiają po rusińsku, tylko że im ta świadomość do niczego nie jest potrzebna" (s. 118). Dwa ostatnie teksty dotyczą konfliktów etniczno-narodowych na omawianym obszarze Europy oraz obecnego kryzysu migracyjnego. Autorzy zauważają, ,że negatywne doświadczenia Czechów, Słowaków czy Węgrów z «własnymi» Romami 
stanowią w tych państwach ważne memento przed otwarciem się na wspomnianych uchodźców" (s. 221).

Białorusinom poświęcony został esej zatytułowany (Nie)obecność wątków białoruskich w ,środkowoeuropejskich " wydawnictwach. Autorzy stwierdzają na początku tekstu:

[...] interesuje nas, na ile obecna w polskiej kulturze moda na tematykę środkowoeuropejską włącza do tego pola tematycznego wątki białoruskie. Przekłada się to na pytanie, czy dziś przez Polaków tematyka białoruska jest postrzegana jako atrakcyjna - ponieważ pojęcie Europy Środkowej niewątpliwie jest nośnikiem tej atrakcyjności, choć dla niszowego grona odbiorców. Skoncentrujemy się na literaturze, choć z pewnością inne dziedziny kultury, takie jak film czy muzyka, również zasługiwałyby na osobne opracowanie (s. 129).

Esej składa się z dwóch części. W pierwszej przedstawiono ustalenia, zgodnie z którymi Białoruś postrzegana jest jako część Europy Środkowej ze względu na jej historię, geopolitykę, kulturę. Druga zawiera odniesienia do wątków białoruskich obecnych w publikacjach dwóch wydawnictw popularyzujących tematykę wspomnianego regionu: wydawnictwo Czarne i Ośrodek „Pogranicze - sztuk, kultur, narodów”.

Autorzy stwierdzają - odwołując się do artykułu Katarzyny Bortnowskiej - że w Polsce Białoruś postrzegana jest praktycznie wyłącznie w wymiarze politycznym. Literatura białoruska zyskała w naszym kraju (w porównaniu z ukraińską) niewielu czytelników. Dalej zauważają - tym razem powołując się na Waldemara Parucha - że Białoruś i Ukraina wyróżniają się spośród społeczeństw środkowoeuropejskich tym, że przejmowanie wzorców zachodnioeuropejskich miało w ich przypadku charakter wtórny, a wpływy niemieckie były/są tam o wiele mniejsze niż w Polsce, Czechach i państwach bałtyckich. Za warunek włączenia Białorusi i Ukrainy do Europy Środkowej Oskar Halecki uznaje niezależność tych państw od Rosji. Jeśli uznamy, że powinna to być nie tylko/nie tyle niezależność ekonomiczna i polityczna, lecz przede wszystkim tożsamościowa, kulturowa, to - jak sądzę - obecna Białoruś do Europy Środkowej nie należy, Ukraina zaś przechodzi pod tym względem od niedawna ewolucję, a do naszej części Europy zaliczyć by można jej część zachodnią, zwłaszcza Galicję (na pewno nie rosyjskojęzyczną, silnie zsowietyzowaną tzw. Noworosję).

W drugiej części eseju autorzy zauważają, że zarówno u Stasiuka oraz Krzysztofa Czyżewskiego, jak i w omawianych wydawnictwach, literatura białoruska (wątki białoruskie) jest ledwie zauważalnym marginesem. Co więcej, żaden z wymienionych pisarzy nie stwierdził nigdy, że Białoruś nie stanowi części Europy Środka. Jedyna białoruska pozycja w wydawnictwie Czarne to książka Artura Klinaua Mińsk. Przewodnik po mieście słońca. Nie ma w niej jednak refleksji na temat przynależności naszego

Marta Cobel-Tokarska i Marcin Dębicki poświęcili wiele uwagi oficynom wydawniczym oraz literatom piszącym o naszej części kontynentu także w innych esejach zamieszczonych w omawianej książce. 
wschodniego sąsiada do kręgu kulturowego Europy Środkowej. Znaną i publikowaną (także przez wydawnictwo Czarne) w Polsce pisarką pochodzącą z Białorusi jest tworząca po rosyjsku Swietłana Aleksijewicz (jedyna białoruska laureatka literackiej Nagrody Nobla), która nie ma silnych związków z ojczystym krajem, a z białoruskością białoruskojęzyczną, narodową - raczej żadne. Zresztą , ,[s]ama Aleksijewicz, mówiąc o sobie - piszą autorzy książki - także podkreśla, że w jej życiu białoruskość nie jest dominującym czynnikiem" (s. 144). W przeciwieństwie do wydawnictwa Czarne sejneńskie Pogranicze nie ma w ofercie ani jednej publikacji pisarza pochodzącego z Białorusi.

Podsumowując rozważania, autorzy omawianego eseju stwierdzają, „że białoruska kultura, historia i literatura nawet dla znawców i propagatorów środkowoeuropejskości pozostaje terra incognita" (s. 146). Powołując się na Bortnowską, wymieniają również - ich zdaniem - przyczyny tego stanu rzeczy:

[...] rozdźwięk między specyfiką białoruskiej literatury a gustami polskich czytelników (gros literatury białoruskiej to poezja lub poetycka proza, w Polsce czytana raczej w umiarkowanym stopniu) oraz fakt, że w Polsce zainteresowanie Białorusią koncentruje się na sferze politycznej, podczas gdy sami białoruscy pisarze od tej problematyki się odżegnują. Prawdopodobny jest zatem scenariusz - dodają M. Cobel-Tokarskia i M. Dębicki - który realizuje się od lat: jedyne książki o Białorusi, które w Polsce są wydawane i mają szanse trafić do grona czytelników szerszego niż profesjonalni białoruteniści, to publikacje opisujące reżim Łukaszenki i reportaże z „białoruskiego skansenu” (s. 147).

Oboje socjologowie mają niewątpliwą rację. Od dekady zainteresowanie Białorusią (białoruskością) narasta przede wszystkim wśród politologów, w znacznie mniejszym stopniu - niekiedy wcale - wśród historyków, literaturoznawców, językoznawców, a zwłaszcza socjologów. Pod koniec tekstu autorzy pytają: ,ile jest środkowoeuropejskości w Białorusi, skoro nawet byty tak otwarte i apolityczne, jak Czarne czy Pogranicze, poświęciły temu państwu tak niewiele uwagi?" (s. 148). 